\title{
Technoloy, Factor Proportions and Complementarity: Trade Relations betwee Korea and Vietnam*
}

\author{
Tran Nhuan Kien**, Yoon Heo***
}

\begin{abstract}
This paper aims at examining the dynamic patterns and traits of bilateral trade between Korea and Vietnam. The major findings of this paper can be summarized as follows. First, the structure of trade between Korea and Vietnam conforms to each country's factor proportion. Second, the structure of Korea's imports from Vietnam did not change over the last two decades. In other words, Vietnam has failed to climb up the industrial ladder. Third, the degree of intra-industry trade between Korea and Vietnam has been low and unstable. Fourth, the trade pattern between Korea and Vietnam has been complementary not competitive in nature. Korea-Vietnam FTA will open a new horizon for the deeper vertical integration of the two.
\end{abstract}

Keywords : Korea-Vietnam FTA, Trade Pattern, Technology Transfer, IIT, TCI

JEL Classification : F15

\footnotetext{
* This paper is a revised and updated version of Kien, Lee and Heo (2010). An earlier version of the paper was presented at Sogang IIAS Research Series (Working Paper) 2012. The authors appreciate the financial support from Sogang University Research Grant 2010.

** Dean, Faculty of Graduate Studies, Thai Nguyen University of Economics and Business Administration, Vietnam; Email: tnkien@tueba.edu.vn

*** Corresponding author, Professor of International Trade, Graduate School of International Studies, Sogang University, Korea; Email: hury@sogang.ac.kr
} 


\section{Introduction}

The diplomatic relation between the Republic of Korea (hereafter, Korea) and Vietnam was officially established in 1992 . With a comprehensive cooperation between the two. the bilateral trade relations between Vietnam and Korea have surged in popularity. The value of Korea's merchandise trade with Vietnam amounted to US\$28.3 billion in 2013, making Korea one of the three biggest trading partners of Vietnam. Recognizing the potential of bilateral trade, the two countries have started negotiations for a free trade agreement to deepen and broaden bilateral trade relations since 2012. The main objective of this paper is to study the changing patterns and traits of bilateral trade relations between the two in recent years, and to derive some policy implications out of it for their future trade relations. This paper is organized as follows. Section II introduces the Korea's FDI into Vietnam in a regional perspective. In section III, the trends and changing patterns of commodity trade between the two are discussed. Section IV assesses the intra-industry trade between Korea and Vietnam. Section V attempts to determine whether bilateral trade between Korea and Vietnam is complementary or competitive in nature. Section VI summarizes the principal findings of this study.

\section{Korea's Foreign Direct Investment into Vietnam}

As soon as the diplomatic relation between the two established, Korean investors started to come into Vietnam as they saw Vietnam as an emerging economy with a large population, abundant and low cost labor force with high literacy rate. Started from over US\$ 100 million in 1992, the registered capital increased to US\$4.294 billion in 2013. In terms of accumulated registered capital, Korea was amongst the top three biggest investors in Vietnam with total of US\$29 billion, just behind Japan and Singapore. It is noteworthy mentioning that the scale of Korea's investment generally was smaller as compared to other investors (on average, the investment amount was US\$8.2 million/project).

In recent year, Korea's investment into Vietnam has increased occupying approximately 10 percent in 2011 and 20 percent in 2013 of Vietnam's total registered foreign capital. The surge in Korea's FDI into Vietnam can be attributed to the two projects of Samsung Electronics in Vietnam. In 2013, Samsung Electronics invested US\$2 billion into a new factory in Thai Nguyen and increased its investment by US\$1 billion in Bac Ninh province (MPI, 2014). Korea's investment in Vietnam has covered various industries, of which the major investment industries have been manufacturing, construction, and real 
estate. The majority of Korea's investment has flowed into manufacturing sector, accounting for 46.3 percent of total Korea's FDI into Vietnam. The second sector that attracted large amount of Korea's investment has been real estate with 28.7 percent, followed by construction sector with 10.7 percent (MPI, 2014).

Table 1.

Korea's Foreign direct investment inflows into Vietnam

\begin{tabular}{|c|c|c|c|c|c|c|c|}
\hline \multirow{2}{*}{ No. } & \multirow{2}{*}{$\begin{array}{l}\text { Country/ } \\
\text { Territory }\end{array}$} & \multicolumn{3}{|c|}{$\begin{array}{l}\text { Registered capital } \\
\text { (billion US\$) }\end{array}$} & \multicolumn{3}{|c|}{ Accumulated number as December 2013} \\
\hline & & 2011 & 2012 & 2013 & $\begin{array}{c}\text { No. of } \\
\text { Projects }\end{array}$ & $\begin{array}{c}\text { Value } \\
\text { (bil. \$) }\end{array}$ & $\begin{array}{c}\text { Percentage } \\
(\%)\end{array}$ \\
\hline 1 & Japan & 2.438 & 5.593 & 5.748 & 2127 & 34.583 & 15.03 \\
\hline 2 & Singapore & 2.208 & 1.938 & 4.377 & 1219 & 29.312 & 12.74 \\
\hline 3 & Korea & 1.467 & 1.285 & 4.294 & 3546 & 29.041 & 12.62 \\
\hline 4 & Taiwan & 0.566 & 2.658 & 0.595 & 2287 & 27.915 & 12.13 \\
\hline 5 & B.V. Islands & 0.481 & 0.822 & 0.307 & 518 & 15.638 & 6.79 \\
\hline 6 & Hong Kong & 3.093 & 0.729 & 0.702 & 760 & 12.595 & 5.47 \\
\hline 7 & USA & 0.254 & 0.160 & 0.125 & 674 & 10.620 & 4.61 \\
\hline 8 & Malaysia & 0.453 & 0.238 & 0.144 & 451 & 10.331 & 4.49 \\
\hline 9 & China & 0.748 & 0.371 & 2.304 & 977 & 6.992 & 3.04 \\
\hline 10 & Thailand & 0.191 & 0.199 & 0.406 & 333 & 6.469 & 2.81 \\
\hline & Total & 14.696 & 16.348 & 21.628 & 15696 & 230.157 & 100 \\
\hline
\end{tabular}

Source: Vietnam's Foreign Investment Agency, 2014

\section{Characteristics and Trends of Korea-Vietnam Trade Relations}

In the late 1980s, bilateral trade between Korea and Vietnam was minimal and unstable (Kien et al., 2010). Since the establishment of diplomatic relations between the two countries, bilateral trade has stably expanded, except for the period during the Asian financial crisis. In particular, Korea's imports from Vietnam have increased more rapidly than Korea's exports to Vietnam. During the period of 1992-2013, the average annual growth rate of Korea's imports from Vietnam was 25.9 percent, whereas Korean exports to Vietnam increased by an average annual growth rate of 20.3 percent. In terms of volume, however, Korea's merchandise exports to Vietnam rose from US\$0.44 billion in 1992 to US $\$ 21.1$ billion in 2013, while its merchandise imports from Vietnam increased from US\$0.06 billion to US\$7.18 billion over the same period. As a result, Vietnam has 
consistently recorded a trade deficit with Korea throughout the period. For example, Vietnam's trade deficit with Korea increased significantly from US\$4.8 billion in 2009 to US\$10.23 billion in 2012 and reached the record level of almost US\$14 billion in 2013. Therefore, this is one of areas that Vietnamese government seriously takes into account when negotiating for a free trade agreement with Korea. However, this is a bilateral illusion due to the exclusion of other export destinations in the analytic picture of total trade balance. In other words, Korea exports huge amounts of parts and components to Vietnam assembling final products and exporting to ASEAN, US and Europe. For example, Samsung Bac Ninh factory is a typical case for the illusion.

Table 2.

Korea's Trade with Vietnam, 1992-2013

\begin{tabular}{|c|c|c|c|c|c|c|}
\hline \multirow{2}{*}{ Year } & \multicolumn{2}{|c|}{ Korea's exports } & \multicolumn{2}{c|}{ Korea's imports } & \multicolumn{2}{c|}{ Total trade } \\
\cline { 2 - 7 } & $\begin{array}{c}\text { Volume } \\
\text { (Mil. \$) }\end{array}$ & $\begin{array}{c}\text { Inc. Rate } \\
\mathbf{( \% )}\end{array}$ & $\begin{array}{c}\text { Volume } \\
\text { (Mil. \$) }\end{array}$ & $\begin{array}{c}\text { Inc. Rate } \\
\mathbf{( \% )}\end{array}$ & $\begin{array}{c}\text { Volume } \\
\text { (Mil. \$) }\end{array}$ & $\begin{array}{c}\text { Inc. Rate } \\
\mathbf{( \% )}\end{array}$ \\
\hline $1987-19911)$ & 92.2 & 50.8 & 29.3 & 26.5 & 121.5 & 44.8 \\
\hline 1992 & 436.2 & 119.2 & 57.3 & 39.3 & 493.5 & 105.5 \\
\hline 1993 & 728.3 & 67.0 & 90.6 & 58.1 & 818.9 & 65.9 \\
\hline 1994 & 1027.4 & 41.1 & 113.8 & 25.5 & 1141.1 & 39.4 \\
\hline 1995 & 1351.0 & 31.5 & 193.6 & 70.2 & 1544.6 & 35.4 \\
\hline 1996 & 1599.1 & 18.4 & 232.0 & 19.9 & 1831.2 & 18.6 \\
\hline 1997 & 1603.1 & 0.3 & 238.6 & 2.8 & 1841.7 & 0.6 \\
\hline 1998 & 1361.4 & -15.1 & 183.8 & -22.9 & 1545.2 & -16.1 \\
\hline 1999 & 1445.2 & 6.2 & 264.2 & 43.7 & 1709.4 & 10.6 \\
\hline 2000 & 1686.0 & 16.7 & 322.4 & 22.0 & 2008.5 & 17.5 \\
\hline 2001 & 1731.7 & 2.7 & 385.8 & 19.6 & 2117.4 & 5.4 \\
\hline 2002 & 2240.2 & 29.4 & 470.3 & 21.9 & 2710.5 & 28.0 \\
\hline 2003 & 2561.2 & 14.3 & 510.7 & 8.6 & 3071.9 & 13.3 \\
\hline 2004 & 3255.6 & 27.1 & 673.3 & 31.8 & 3928.9 & 27.9 \\
\hline 2005 & 3431.7 & 5.4 & 694.0 & 3.1 & 4125.7 & 5.0 \\
\hline 2006 & 3927.5 & 14.5 & 924.9 & 33.3 & 4852.3 & 17.6 \\
\hline 2007 & 5760.1 & 46.7 & 1391.6 & 50.5 & 7151.6 & 47.4 \\
\hline 2008 & 7804.8 & 35.5 & 2037.1 & 46.4 & 9841.9 & 37.6 \\
\hline 2009 & 7149.5 & -8.4 & 2370.0 & 16.3 & 9519.4 & -3.3 \\
\hline 2010 & 9652.1 & 35.0 & 3330.8 & 40.5 & 12982.9 & 36.4 \\
\hline 2011 & 13464.9 & 39.5 & 5084.2 & 52.6 & 18549.2 & 42.9 \\
\hline 2012 & 15946.0 & 18.4 & 5719.25 & 12.5 & 21665.25 & 16.8 \\
\hline 2013 & 21087.6 & 32.2 & 7175.19 & 25.5 & 28262.77 & 30.5 \\
\hline
\end{tabular}

note 1) Average of the period 
Samsung Electronics Vietnam (SEV) exported about US\$ 12.5 billion in 2012 and record high US\$ 24.5 billion in 2013. This figure reaches almost $20 \%$ of Vietnam's total amount of export. This trend will accelerate as SEV opens its new factory in Thai Nguyen in March 2013. With the surge in SEV's exports of electronic products, Vietnam's trade balance turned into surplus in 2013.

Even though Vietnam has a large bilateral trade deficit with Korea, its exports to Korea increased significantly in the last 5 years despite the recession due to the global economic downturn. The annual growth rate of Vietnam's exports to Korea was 31.9 percent during 2009-2013 period. This increase contributed to the overall Korea-Vietnam trade expansion in recent years (Table 2). The implementation of the Korea-ASEAN FTA may be one of the factors contributing to this significant increase. As a result, Korea and Vietnam have been each other's important trading partners. For Korea, the role of Vietnam's market has been increasing in recent years. In 2013, Vietnam was the 5th largest export market and the 16th import market. Overall, Vietnam was the 8th largest trading partner of Korea in 2013. For Vietnam, Korea has been one of the major trading partners. During 2011-2013, Korea has been considered as Vietnam's 4th largest export market and was ranked 2nd in Vietnam's source of imports. In 2013, Korea was the 3rd largest trading partner of Vietnam with the total merchandise trade recorded US\$28.3 billion, an increase of 30.5 percent compared to the previous year.

Looking at the Korea-Vietnam commodity trade, Tables 3 and 4 show the main products traded between Korea and Vietnam. It has been demonstrated that the structure of Vietnam's exports to Korea are quite different from Korea's exports to Vietnam. Our analysis shows that Korea's major export items to Vietnam are consisted of capital goods, parts and components of machinery, steel/metal products, and industrial textiles, whereas Vietnam has principally exported primary products - such as agricultural and fishery products and consumer textiles - over the past two decades. In addition, the structure of trade has changed little or very gradually. This is a typical inter-industry trade pattern in North-south trade. In the next section, the paper will discuss the issue of inter-industry trade between Korea and Vietnam in a greater detail. 
Table 3.

Top 10 Korean Exports to Vietnam (SITC 3-digit of Rev.2)

\begin{tabular}{|c|c|c|c|}
\hline 1995 & 2000 & 2005 & 2011 \\
\hline $\begin{array}{l}\text { Woven man-made } \\
\text { fiber fabric (10.1) }\end{array}$ & $\begin{array}{c}\text { Special textile fabric } \\
\text { products }(8.9)\end{array}$ & $\begin{array}{l}\text { Petroleum products, } \\
\text { refined (11.3) }\end{array}$ & $\begin{array}{l}\text { Telecommunication } \\
\text { equipment parts (10.9) }\end{array}$ \\
\hline $\begin{array}{c}\text { Polymerization etc. } \\
\text { products }(6.6)\end{array}$ & $\begin{array}{l}\text { Polymerization etc. } \\
\text { products }(7.6)\end{array}$ & $\begin{array}{l}\text { Telecommunication } \\
\text { equip. and parts }(6.2)\end{array}$ & $\begin{array}{l}\text { Petroleum products, } \\
\text { refined (8.1) }\end{array}$ \\
\hline $\begin{array}{l}\text { Special textile fabric } \\
\text { products }(5.8)\end{array}$ & $\begin{array}{l}\text { Woven man-made } \\
\text { fiber fabric (5.8) }\end{array}$ & $\begin{array}{l}\text { Knitted or crocheted } \\
\text { fabrics }(6.1)\end{array}$ & $\begin{array}{l}\text { Iron, steel primary } \\
\text { forms }(7.4)\end{array}$ \\
\hline $\begin{array}{l}\text { Lorries, special motor } \\
\text { vehicles n.e.s. }(4.2)\end{array}$ & $\begin{array}{l}\text { Petroleum products, } \\
\text { refined (4.6) }\end{array}$ & $\begin{array}{l}\text { Polymerization etc. } \\
\text { products }(6.0)\end{array}$ & $\begin{array}{l}\text { Knitted or crocheted } \\
\text { fabrics }(5.9)\end{array}$ \\
\hline $\begin{array}{c}\text { Television receivers } \\
(4.2)\end{array}$ & $\begin{array}{l}\text { Lorries, special motor } \\
\text { vehicles n.e.s. (4.4) }\end{array}$ & $\begin{array}{l}\text { Special textile fabric } \\
\text { products }(5.4)\end{array}$ & $\begin{array}{l}\text { Transistors, valves, } \\
\text { etc. (5.1) }\end{array}$ \\
\hline $\begin{array}{l}\text { Petroleum products, } \\
\text { refined (4.0) }\end{array}$ & Leather (4.0) & $\begin{array}{l}\text { Lorries, special motor } \\
\text { vehicles n.e.s. (5.1) }\end{array}$ & $\begin{array}{l}\text { Polymerization etc. } \\
\text { products }(4.2)\end{array}$ \\
\hline $\begin{array}{c}\text { Iron, steel universal } \\
\text { plate, sheet (3.4) }\end{array}$ & $\begin{array}{c}\text { Leather etc. } \\
\text { manufactures (3.5) }\end{array}$ & $\begin{array}{l}\text { Woven man-made } \\
\text { fabric (4.6) }\end{array}$ & $\begin{array}{l}\text { Electrical machinery } \\
\text { and apparatus, (3.2) }\end{array}$ \\
\hline $\begin{array}{l}\text { Textile \& leather } \\
\text { machinery (3.3) }\end{array}$ & $\begin{array}{c}\text { Knitted or crocheted } \\
\text { fabrics }(3.5)\end{array}$ & $\begin{array}{l}\text { Textile\& leather } \\
\text { machinery }(2.8)\end{array}$ & $\begin{array}{c}\text { Switchgear etc. parts } \\
\text { n.e.s. }(3.1)\end{array}$ \\
\hline $\begin{array}{l}\text { Mach.\& equipment for } \\
\text { special industries (3.3) }\end{array}$ & $\begin{array}{c}\text { Cycles, etc. motorized } \\
\text { or not }(2.9)\end{array}$ & $\begin{array}{l}\text { Iron, steel universal } \\
\text { plate, sheet }(2.8)\end{array}$ & $\begin{array}{l}\text { Iron, steel universal } \\
\text { plate, sheet }(2.9)\end{array}$ \\
\hline $\begin{array}{l}\text { Cycles, etc. motorized } \\
\text { or not }(2.8)\end{array}$ & Textile yarn (2.7) & Leather (2.6) & $\begin{array}{c}\text { Production of } \\
\text { condensation, etc. } \\
(2.6)\end{array}$ \\
\hline
\end{tabular}

Note: Numbers in the parentheses denote the percentage share of the product in Korea's exports to Vietnam. Source: Authors' calculation based on database of UNSD 2014.

In 2011, the top 10 products exported from Korea to Vietnam in total accounted for nearly 54 percent of Korea's total exports whereas the top 10 products exported from Vietnam to Korea made up 58 percent of Vietnam's total exports. This indicates that Vietnam's exports to Korea were less diversified than those of Korea. When taking into account the changes in structure of exports, it becomes clear that the technology level of these products has increased. For example, telecommunication equipment parts replaced leather and leather manufactured goods as the major export items from Korea to Vietnam. 


\section{Table 4.}

Top 10 Korean Imports from Vietnam (SITC 3-digit of Rev.2)

\begin{tabular}{|c|c|c|c|}
\hline 1995 & 2000 & 2005 & 2011 \\
\hline $\begin{array}{l}\text { Coffee and substitutes } \\
\qquad(17.1)\end{array}$ & $\begin{array}{l}\text { Shell fish, fresh, } \\
\text { frozen }(12.8)\end{array}$ & $\begin{array}{l}\text { Shell fish, fresh, } \\
\text { frozen }(13.0)\end{array}$ & $\begin{array}{c}\text { Crude petroleum } \\
\text { (18.1) }\end{array}$ \\
\hline $\begin{array}{l}\text { Woven man-made } \\
\text { fiber fabric }(7.6)\end{array}$ & $\begin{array}{l}\text { Vegetables, fresh, } \\
\text { chilled, frozen }(6.7)\end{array}$ & Textile yarn (8.1) & $\begin{array}{l}\text { Men's outerwear not } \\
\text { knit }(6.9)\end{array}$ \\
\hline $\begin{array}{c}\text { Cotton fabrics, woven } \\
\text { (7.5) }\end{array}$ & $\begin{array}{l}\text { Men's outerwear } \\
\text { non-knitted }(6.1)\end{array}$ & Footwear (6.7) & Textile yarn (6.2) \\
\hline $\begin{array}{c}\text { Coal, lignite, and peat } \\
\text { (4.8) }\end{array}$ & $\begin{array}{l}\text { Coffee and substitutes } \\
\qquad(5.3)\end{array}$ & $\begin{array}{l}\text { Furniture, parts thereof } \\
\qquad(6.1)\end{array}$ & $\begin{array}{l}\text { Shell fish fresh, frozen } \\
\text { (5.6) }\end{array}$ \\
\hline $\begin{array}{l}\text { Travel goods, } \\
\text { handbags (4.3) }\end{array}$ & $\begin{array}{l}\text { Fish etc. prepared, } \\
\text { preserved n.e.s. }(4.5)\end{array}$ & $\begin{array}{l}\text { Fish, fresh, chilled or } \\
\text { frozen }(5.1)\end{array}$ & $\begin{array}{l}\text { Women's outerwear } \\
\text { not knit }(5.0)\end{array}$ \\
\hline $\begin{array}{l}\text { Shell fish, fresh, } \\
\text { frozen (3.8) }\end{array}$ & $\begin{array}{l}\text { Fish, fresh, chilled, } \\
\text { frozen (4.5) }\end{array}$ & $\begin{array}{l}\text { Fish, etc. prepared, } \\
\text { preserved n.e.s. (4.8) }\end{array}$ & Footwear (4.8) \\
\hline $\begin{array}{c}\text { Men's outerwear not } \\
\text { knitted (3.6) }\end{array}$ & $\begin{array}{l}\text { Furniture and parts } \\
\text { thereof (4.1) }\end{array}$ & $\begin{array}{l}\text { Natural rubber, gums } \\
\qquad(4.6)\end{array}$ & $\begin{array}{l}\text { Coal, lignite and peat } \\
\qquad(4.0)\end{array}$ \\
\hline $\begin{array}{l}\text { Fruit, preserved, } \\
\text { prepared }(3.5)\end{array}$ & $\begin{array}{l}\text { Natural rubber, gums } \\
\qquad(3.1)\end{array}$ & $\begin{array}{c}\text { Coffee and coffee } \\
\text { substitutes }(4.2)\end{array}$ & $\begin{array}{l}\text { Electrical machinery } \\
\text { and apparatus (2.6) }\end{array}$ \\
\hline Aircraft, etc. (3.5) & Textile yarn (3.1) & $\begin{array}{l}\text { Coal, lignite and peat } \\
\text { (3.6) }\end{array}$ & $\begin{array}{l}\text { Furniture, parts thereof } \\
\qquad(2.5)\end{array}$ \\
\hline $\begin{array}{l}\text { Headgear, non-textile } \\
\text { clothing (3.4) }\end{array}$ & $\begin{array}{l}\text { Headgear, non-textile } \\
\text { clothing (3.1) }\end{array}$ & $\begin{array}{l}\text { Vegetables, fresh, } \\
\text { chilled, preserved (2.9) }\end{array}$ & $\begin{array}{c}\text { Natural rubber, gums } \\
(2.3)\end{array}$ \\
\hline
\end{tabular}

Note: Numbers in parentheses denote the percentage share of the product in Korea's exports to Vietnam. Source: Authors' calculation based on database of UNSD 2014

Another major change in Korea's exports to Vietnam is that import substitution by Vietnam for its imports from Korea has made progress only in low technology goods, most notably fabric products. For example, woven man-made fabric ranked first among the top 10 products exported from Korea to Vietnam in 1995, but its ranking fell to third in 2000, and fell further in 2005, to seventh, and left the top 10 product groups in 2011. This can be explained either by Vietnam having upgraded its production capacity for these products, or by Vietnam having begun to import these goods from cheaper sources, such as China. Another explanation might be that Korea's comparative advantage in this product group has deteriorated over the past decade. 


\section{Table 5.}

Korea's Exports to Vietnam by Stage of Production (unit: percent)

\begin{tabular}{|c|c|c|c|c|c|c|c|c|c|c|c|c|}
\hline & 1995 & 1997 & 1999 & 2001 & 2003 & 2005 & 2006 & 2007 & 2008 & 2009 & 2010 & 2011 \\
\hline Primary goods & 0.3 & 0.7 & 0.4 & 0.3 & 0.4 & 0.6 & 0.6 & 0.6 & 0.8 & 0.9 & 0.6 & 0.9 \\
\hline $\begin{array}{l}\text { Intermediate } \\
\text { goods }\end{array}$ & 68.2 & 79.2 & 79.8 & 68.5 & 65.2 & 67.2 & 70.4 & 68.2 & 70.4 & 68.1 & 75.4 & 77.7 \\
\hline $\begin{array}{l}\text { Semi-finished } \\
\text { goods }\end{array}$ & 63.4 & 72.0 & 72.6 & 60.6 & 56.7 & 58.4 & 62.2 & 59.5 & 61.0 & 56.5 & 57.8 & 51.4 \\
\hline $\begin{array}{c}\text { Parts \& } \\
\text { components }\end{array}$ & 4.8 & 7.2 & 7.2 & 8.0 & 8.5 & 8.8 & 8.2 & 8.7 & 9.4 & 11.6 & 17.7 & 26.4 \\
\hline Final goods & 31.5 & 20.2 & 19.8 & 31.1 & 34.4 & 32.2 & 29.0 & 31.2 & 28.9 & 31.0 & 23.9 & 21.4 \\
\hline Capital goods & 15.8 & 11.1 & 9.3 & 21.7 & 25.0 & 23.9 & 21.2 & 20.2 & 18.0 & 18.6 & 14.4 & 12.8 \\
\hline $\begin{array}{l}\text { Consumption } \\
\text { goods }\end{array}$ & 15.6 & 9.0 & 10.5 & 9.4 & 9.4 & 8.3 & 7.7 & 11.0 & 10.9 & 12.4 & 9.5 & 8.6 \\
\hline
\end{tabular}

Source: Authors' calculation based on database of UNSD 2014, using classification of Gaulier, Lemoine, and Kesenci, 2005.

The structure of commodity trade between Korea and Vietnam becomes more apparent when bilateral trade is classified in terms of stage of production. One of the most transparent patterns of trade between the two is the high share of intermediate goods in Korean exports and of final goods in Korean imports. In Korea's exports of intermediate products to Vietnam, the share of semi-finished products accounted for a large part, even though its share has gradually declined in recent years. On the other hand, Korea's exports of parts and components have increased sharply in recent years, reflecting the interdependency between the two countries. On the import side, Korea's imports of primary and final goods accounted for over 70 percent of total imports. Korea's imports of consumption goods from Vietnam increased during the mid-2000s but then the share declined during 2007-2011. Overall, we witnessed that the structure of Korea's imports from Vietnam did not change over time.

The large share of semi-finished goods in Vietnam's imports and of consumption goods in Vietnam's exports reflects a deepening bilateral trade and cooperation in investments between the two countries, in which Vietnam took the final process in the entire value-chain of production. It can be asserted that this pattern may be the consequence 
of the increases in FDI inflows from Korea to Vietnam, because Vietnam offers an abundance of low-cost labor and land, as well as favorable governmental policies (Kien, et al., 2010). This also implies that Vietnam's exports are relatively low in terms of added value, as assembly is the primary final process in Vietnamese production.

\section{Table 6.}

Korea's Imports from Vietnam by Stage of Production (unit: percent)

\begin{tabular}{|c|ccccccccccccc|}
\hline & 1995 & 1997 & $\mathbf{1 9 9 9}$ & $\mathbf{2 0 0 1}$ & $\mathbf{2 0 0 3}$ & $\mathbf{2 0 0 5}$ & $\mathbf{2 0 0 6}$ & $\mathbf{2 0 0 7}$ & $\mathbf{2 0 0 8}$ & $\mathbf{2 0 0 9}$ & $\mathbf{2 0 1 0}$ & $\mathbf{2 0 1 1}$ \\
\hline Primary goods & 32.6 & 24.2 & 27.6 & 19.0 & 18.3 & 19.0 & 20.3 & 26.4 & 30.3 & 31.6 & 31.3 & 30.7 \\
$\begin{array}{c}\text { Intermediate } \\
\text { goods }\end{array}$ & 25.0 & 24.2 & 30.7 & 20.9 & 21.5 & 22.5 & 22.1 & 22.7 & 25.6 & 26.9 & 30.0 & 27.9 \\
$\begin{array}{c}\text { Semi-finished } \\
\text { goods }\end{array}$ & 22.0 & 18.4 & 25.1 & 15.1 & 15.7 & 19.5 & 20.4 & 21.5 & 24.3 & 22.0 & 24.7 & 22.1 \\
$\quad$ Parts \& \\
components \\
$\begin{array}{c}\text { Final goods } \\
\text { Capital goods }\end{array}$
\end{tabular}

Source: Authors' calculation based on database of UNSD 2012, using classifications of Gaulier, Lemoine, and Kesenci, 2005.

Using the methodology of Lall (2000), exports and imports of the two countries are classified into four categories: resource-based, low-technology, medium-technology, and high-technology in order to clarify the technological level in each country's trade. Tables 7 and 8 show the growth rates and market shares of Korea-Vietnam trade according to technological level. Several important notions can be derived from these results. Overall, Korea's exports to and imports from Vietnam are reflective of normal trade patterns between a developed and a developing country. Almost all Korean exports to Vietnam are manufactured goods, accounting for more than $95 \%$ of the total in 2011. 
Table 7.

Korea's Exports to Vietnam by Technological Level

(Unit: percent)

\begin{tabular}{|l|c|c|c|c|c|c|}
\hline \multicolumn{1}{|c|}{ Product Name } & $\mathbf{1 9 9 5}$ & $\mathbf{2 0 0 0}$ & $\mathbf{2 0 0 5}$ & $\mathbf{2 0 1 0}$ & $\mathbf{2 0 1 1}$ & $\begin{array}{c}\text { GR } \\
\mathbf{9 5 - 2 0 1 1}\end{array}$ \\
\hline A. Primary Products & $\mathbf{3 . 0}$ & $\mathbf{2 . 4}$ & $\mathbf{3 . 9}$ & $\mathbf{4 . 5}$ & $\mathbf{4 . 5}$ & $\mathbf{1 8 . 3}$ \\
\hline B. Manufactured & $\mathbf{9 7 . 0}$ & $\mathbf{9 7 . 6}$ & $\mathbf{9 6 . 1}$ & $\mathbf{9 5 . 5}$ & $\mathbf{9 5 . 5}$ & $\mathbf{1 5 . 3}$ \\
\hline 1. Resource-based & 10.1 & 11.0 & 16.0 & 13.9 & 13.2 & 17.4 \\
\hline Agro-based & 3.5 & 3.3 & 2.6 & 2.9 & 3.2 & 14.8 \\
\hline Mineral-based & 6.6 & 7.7 & 13.4 & 11.0 & 10.0 & 18.5 \\
\hline 2. Low technology & 31.2 & 36.7 & 31.7 & 22.3 & 20.1 & 12.3 \\
\hline Fashion cluster & 19.3 & 27.1 & 23.4 & 14.6 & 12.7 & 12.5 \\
\hline Other Product & 11.9 & 9.5 & 8.3 & 7.7 & 7.4 & 12.1 \\
\hline 3. Medium technology & 46.7 & 43.2 & 37.3 & 45.2 & 39.5 & 14.2 \\
\hline Automotive & 9.9 & 10.4 & 8.9 & 8.9 & 7.0 & 12.9 \\
\hline Process & 22.8 & 19.9 & 17.5 & 24.2 & 21.1 & 14.9 \\
\hline Engineering & 14.0 & 12.9 & 10.9 & 12.0 & 11.3 & 13.9 \\
\hline 4. High technology & 8.9 & 6.9 & 11.1 & 14.1 & 22.7 & 22.4 \\
\hline Electronic and electrical & 7.8 & 4.7 & 9.3 & 12.2 & 20.8 & 22.8 \\
\hline Other & 1.2 & 2.2 & 1.8 & 1.9 & 1.8 & 18.6 \\
\hline Total & 100 & 100 & 100 & 100 & 100 & 15.5 \\
\hline
\end{tabular}

Note : ${ }^{1)}$ Authors' calculation based on database of UNSD 2014

Among manufactured goods, exports concentrate on fashion cluster, electronic and electrical products, engineering and process products. In particular, exports of high-technology manufactured goods have increased significantly from 9 percent in 1995 to 23 percent of the total in 2011, or an average annual growth rate of 22.4 percent over the period. 
Table 8.

Korea's Imports from Vietnam by Technological Level

(Unit: percent)

\begin{tabular}{|l|c|c|c|c|c|c|}
\hline \multicolumn{1}{|c|}{ Product Name } & $\mathbf{1 9 9 5}$ & $\mathbf{2 0 0 0}$ & $\mathbf{2 0 0 5}$ & $\mathbf{2 0 1 0}$ & $\mathbf{2 0 1 1}$ & $\begin{array}{c}\text { GR } \\
\mathbf{9 5 - 2 0 1 1}\end{array}$ \\
\hline A. Primary Products & $\mathbf{4 1 . 3}$ & $\mathbf{3 7 . 2}$ & $\mathbf{3 7 . 7}$ & $\mathbf{4 0 . 6}$ & $\mathbf{3 8 . 7}$ & $\mathbf{2 2 . 2}$ \\
\hline B. Manufactured & $\mathbf{5 8 . 7}$ & $\mathbf{6 2 . 8}$ & $\mathbf{6 2 . 3}$ & $\mathbf{5 9 . 4}$ & $\mathbf{6 1 . 3}$ & $\mathbf{2 3 . 0}$ \\
\hline 1. Resource-based & 7.3 & 10.6 & 10.4 & 7.9 & 7.5 & 22.9 \\
\hline Agro-based & 6.9 & 6.8 & 7.4 & 5.3 & 4.8 & 19.9 \\
\hline Mineral-based & 0.4 & 3.8 & 3.0 & 2.6 & 2.6 & 39.0 \\
\hline 2. Low technology & 35.9 & 36.7 & 38.3 & 36.9 & 37.9 & 23.1 \\
\hline Fashion cluster ${ }^{1)}$ & 32.5 & 28.6 & 28.2 & 29.1 & 31.6 & 22.4 \\
\hline Other Product & 3.3 & 8.0 & 10.1 & 7.8 & 6.3 & 27.7 \\
\hline 3. Medium technology & 8.2 & 6.4 & 5.1 & 6.9 & 7.8 & 22.3 \\
\hline Automotive & 0.0 & 0.0 & 0.1 & 0.4 & 0.5 & 53.1 \\
\hline Process & 7.7 & 2.8 & 2.8 & 2.9 & 4.3 & 18.2 \\
\hline Engineering & 0.5 & 3.5 & 2.2 & 3.6 & 3.1 & 37.5 \\
\hline 4. High technology & 7.4 & 9.2 & 8.5 & 7.8 & 8.1 & 23.4 \\
\hline Electronic and electrical & 3.9 & 9.0 & 8.3 & 7.7 & 7.4 & 27.7 \\
\hline Other & 3.5 & 0.3 & 0.2 & 0.1 & 0.7 & 10.8 \\
\hline Total & 100 & 100 & 100 & 100 & 100 & 22.7 \\
\hline
\end{tabular}

Note : ${ }^{1)}$ Textile, garment and footwear

Source : Authors' calculation based on database of UNSD 2014

Vietnam's exports to Korea reflect the country's abundant natural resource endowments as well as competitive labor force, both of which are disadvantages of Korea. Vietnam focuses on exporting primary products, resource based goods, and lowtechnology sector goods to Korea. Indeed, primary products account for approximately 39 percent of total Korean imports in 2011, whereas low-technology imports account for nearly 38 percent of the total. Among manufactured products, Korea's fashion cluster import records the largest amount, which is almost 32 percent of total imports into Korea. For the whole period, the imports of engineering products show a high growth rate and are much higher than the average growth rate of total manufactured exports. Overall, for the 
past two decades, in terms of trade patterns between Korea and Vietnam, we can conclude that the vertical integration through production sharing between the two has deepened and broadened while contrary to China, Vietnam has constantly failed to climb the industrial staircase from resource and labor driven stage towards capital and technology intensive one.

\section{Korea-Vietnam's Intra-industry Trade}

The intra-industry trade (IIT) is commonly measured by the Grubel-Lloyd index, which ranges between zero and unity - a zero is interpreted as complete inter-industry trade, whereas a unity would denote a completely intra-industry trade. We summarized the result of IIT between Korea and Vietnam in Table 9. The results show that the major trade between Korea and Vietnam has been inter-industry. This suggests that economies of scale between the two countries are not being exploited. The main bulks of product groups have very low IIT indices. In 1995, for example, approximately 90 percent of the total 189 product groups fell within an IIT index range of 0.00 to 0.25 (very low intra-industry trade). This result shows that Korea and Vietnam are quite divergent in their development stages. In recent years, the degree of intra-industry trade in Korea-Vietnam bilateral trade has increased gradually. The share of high IIT indices (from 0.75 to 1.00) increased from 1.6 percent in 1995 to 8.2 percent in 2011, whereas the share of low IIT indices declined gradually, to approximately 65.3 percent.

Table 9.

Distribution of IIT Index of Korea-Vietnam Trade, 1995-2011

\begin{tabular}{|c|c|c|c|c|c|c|c|c|}
\hline \multirow{2}{*}{ IIT Band } & \multicolumn{2}{|c|}{1995} & \multicolumn{2}{c|}{2000} & \multicolumn{2}{c|}{2005} & \multicolumn{2}{c|}{2011} \\
\cline { 2 - 9 } & $\begin{array}{c}\text { No. of } \\
\text { product } \\
\text { groups }\end{array}$ & Percent & $\begin{array}{c}\text { No. of } \\
\text { product } \\
\text { groups }\end{array}$ & Percent & $\begin{array}{c}\text { No. of } \\
\text { product } \\
\text { groups }\end{array}$ & Percent & $\begin{array}{c}\text { No. of } \\
\text { product } \\
\text { groups }\end{array}$ & Percent \\
\hline $0.00 \prec 0.25$ & 170 & 89.9 & 167 & 82.3 & 160 & 75.5 & 143 & 65.3 \\
\hline $0.25<0.50$ & 8 & 4.2 & 13 & 6.4 & 19 & 9.0 & 31 & 14.2 \\
\hline $0.50<0.75$ & 8 & 4.2 & 15 & 7.4 & 16 & 7.5 & 27 & 12.3 \\
\hline $0.75-1.00$ & 3 & 1.6 & 8 & 3.9 & 17 & 8.0 & 18 & 8.2 \\
\hline Total $^{1)}$ & 189 & 100 & 203 & 100 & 212 & 100 & 219 & 100 \\
\hline
\end{tabular}

Note $:{ }^{1)}$ the actual number of product groups traded between Korea and Vietnam at the three digit of SITC (total 266 product groups).

Source: Authors' calculation based on the UNSD 2014 database 
At three-digit product groups, we find that all groups with high intra-industry trade fall within product groups of SITC five, six, seven, and eight (at the one-digit level), which are manufacturing industries. This is not surprising since intra-industry trade is of greater importance in manufacturing industries, in which product differentiation and scale economies are more prevalent than in other economic sectors. The highest IIT index in the trade between Korea and Vietnam was for furniture and parts thereof (821) in 1995, pesticide disinfectants (591) in 2000, pearls, precious and semi-precious stones (667) in 2005, and animal \& vegetable oils and fats (431) in 2011. It is worth mentioning that the 10 highest intra-industry trade indices between Korea and Vietnam differed at different times. This indicates that the intra-industry trade between the two has been somewhat precarious. 


\begin{tabular}{|c|c|c|c|c|c|c|c|c|c|c|c|c|}
\hline \multirow{3}{*}{ 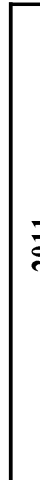 } & 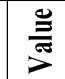 & $\begin{array}{l}: \\
\end{array}$ & $\stackrel{\leftrightarrow}{\circ}$ & $\begin{array}{ll}9 \\
g \\
g\end{array}$ & $\tilde{\delta}$ & $\bar{\sigma}$ & 8 & $\tilde{D}_{\infty}^{\infty}$ & $\stackrel{0}{\circ}$ & $\stackrel{\infty}{\infty}$ & {$\left[\begin{array}{ll}a \\
0 \\
0\end{array}\right.$} & $\overline{0}$ \\
\hline & 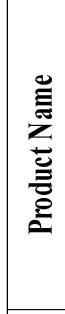 & 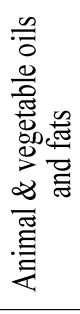 & 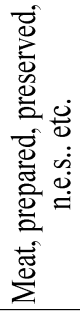 & 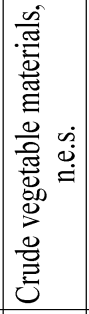 & 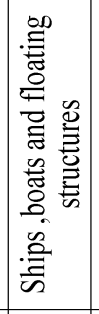 & 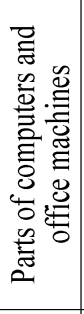 & 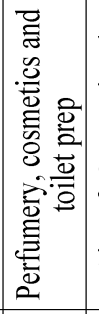 & 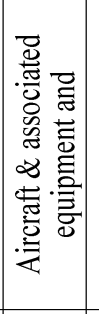 & 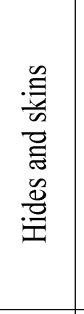 & 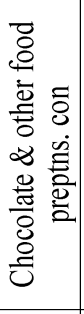 & 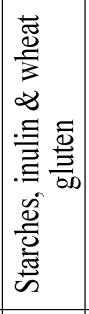 & \\
\hline & हैँ & $\bar{q}$ & $\stackrel{t}{\sigma}$ & ลี & $\stackrel{R}{2}$ & हे & $\stackrel{2}{2}$ & $\check{\Sigma}$ & $\overline{\bar{\lambda}}$ & $\tilde{\delta}$ & 吕 & \\
\hline \multirow{3}{*}{ ڤે } & 总 & ga & ga & $\stackrel{\circ}{\circ}$ & $\stackrel{\circ}{\circ}$ & 落 & g̊ & ${ }_{0}^{\infty}$ & $\stackrel{\infty}{\infty}$ & $\underset{\infty}{\infty}$ & $\begin{array}{l}\infty \\
\infty \\
\infty\end{array}$ & $=$ \\
\hline & 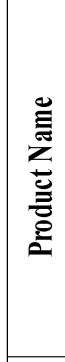 & 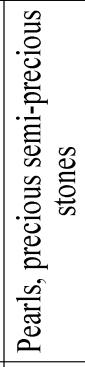 & 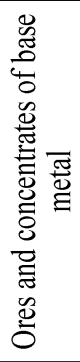 & 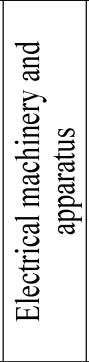 & 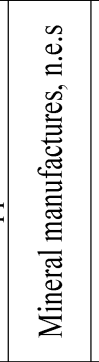 & 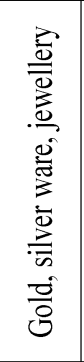 & 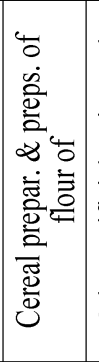 & 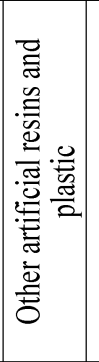 & 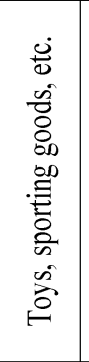 & 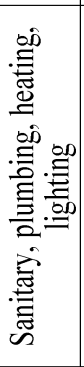 & 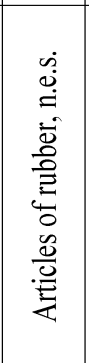 & \\
\hline & 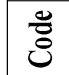 & 5 & $\bar{\sim}$ & $\stackrel{\infty}{\Sigma}$ & 8 & $\bar{\infty}$ & 舟 & $\infty$ & 㕝 & $\stackrel{\simeq}{\infty}$ & 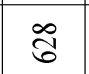 & \\
\hline \multirow{3}{*}{ ถิ } & 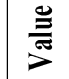 & 苂 & 总 & $\stackrel{8}{\circ}$ & 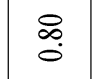 & E. & $\stackrel{\text { : }}{\circ}$ & $\stackrel{0}{0}$ & $\stackrel{0}{\circ}$ & 苦 & 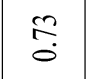 & $\because$ \\
\hline & 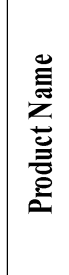 & 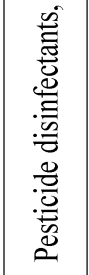 & 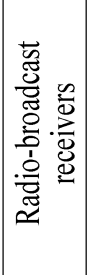 & 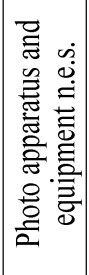 & 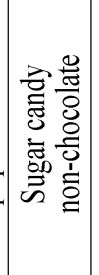 & 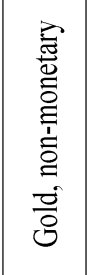 & 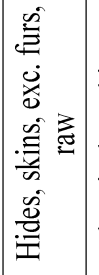 & 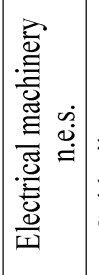 & 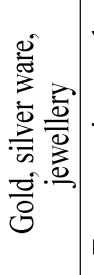 & 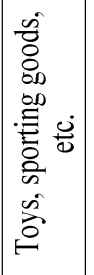 & 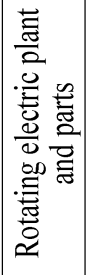 & \\
\hline & हี & $\bar{b}$ & 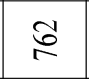 & $\bar{ळ}$ & 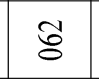 & $\Sigma$ & $\overline{\bar{\sim}}$ & $\stackrel{\infty}{\vDash}$ & Бे & \begin{tabular}{|c|} 
I \\
\end{tabular} & $\stackrel{\circ}{\circ}$ & \\
\hline & 异 & g. & $\bar{g}$ & E & $\begin{array}{l}\stackrel{r}{o} \\
o\end{array}$ & ?: & : & $\stackrel{\infty}{0}$ & $\stackrel{5}{0}$ & 志 & $\begin{array}{l}8 \\
0\end{array}$ & $\stackrel{+}{+}$ \\
\hline : & 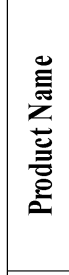 & 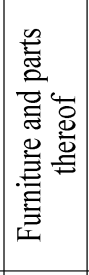 & 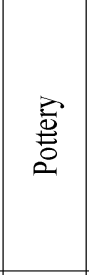 & 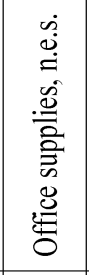 & 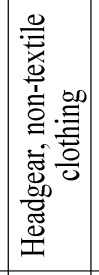 & 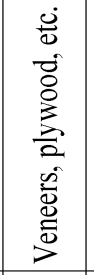 & 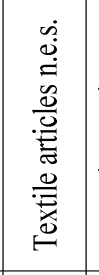 & 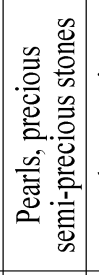 & 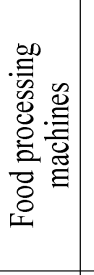 & 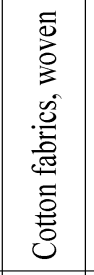 & 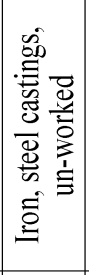 & 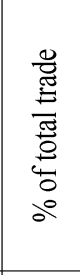 \\
\hline & है요 & $\bar{\infty}$ & : & : & $\begin{array}{l}\infty \\
\infty \\
\infty\end{array}$ & 志 & $\stackrel{\infty}{6}$ & 5 & $\bar{a}$ & $\tilde{3}$ & $\hat{b}$ & \\
\hline
\end{tabular}




\section{Comparative Advantages of Korea and Vietnam's Exports}

To find the comparative advantages in trade between Korea and Vietnam, it is noteworthy to calculate and compare the revealed comparative advantage indices for Korea and Vietnam. The RCA indices for the top 10 export products of Vietnam are shown in Table 11. The RCA index is calculated for product groups at the three-digit SITC level, and is ranked by RCA index values in 2012. Overall, Vietnam enjoyed a comparative advantage largely in either primary products or low-technology manufactured goods.

High-comparative advantage product groups of Vietnam across the time span included rice (042), spices (075), coffee and coffee substitutes (071), footwear (851), shellfish fresh or frozen (036). Several product groups evidenced significant increases in comparative advantage over time: photographic apparatus and equipment (881), pulpwood (246). It is shown that Vietnam has a very strong comparative advantage in agriculture products particular rice, rubber, fish, and coffee. These areas would bring forward a strong comparative advantage over Korea when the two countries establish a FTA. Therefore, Vietnam should negotiate hard on this issue during the negotiation of the agreement.

\section{Table 11.}

Vietnam's Top 10 Products of High Comparative Advantages

\begin{tabular}{|c|cccccc|}
\hline Code & Product name & $\mathbf{1 9 9 7}$ & $\mathbf{2 0 0 0}$ & $\mathbf{2 0 0 5}$ & $\mathbf{2 0 0 9}$ & $\mathbf{2 0 1 2}$ \\
\hline 881 & $\begin{array}{c}\text { Photographic apparatus and } \\
\text { equipment, n.e.s. }\end{array}$ & 0.03 & 0.32 & 0.35 & 13.68 & 33.10 \\
& Rice & 71.17 & 45.18 & 43.89 & 29.99 & 22.62 \\
246 & Pulpwood & 5.36 & 2.43 & 11.30 & 12.45 & 19.68 \\
075 & Spices & 22.57 & 26.86 & 18.58 & 17.57 & 17.38 \\
071 & Coffee and coffee substitutes & 18.72 & 19.22 & 15.28 & 15.52 & 13.38 \\
851 & Footwear & 13.76 & 15.32 & 15.87 & 11.54 & 10.36 \\
036 & Shellfish fresh, frozen & 22.03 & 31.66 & 28.48 & 18.13 & 10.34 \\
232 & Natural rubber, gums & 21.32 & 18.85 & 23.08 & 20.30 & 10.12 \\
842 & Outer garments, men's, of textile & 12.91 & 7.83 & 6.97 & 7.03 & 7.92 \\
& fabrics & 2.93 & 3.62 & 6.00 & 8.96 & 6.93 \\
\hline \multirow{2}{*}{034} & Fish, fresh, chilled or frozen & & & & & \\
\hline
\end{tabular}

Source: Authors' calculation based on database of UNSD 2014 
Table 12.

Korea's Top 10 Products of High Comparative Advantages

\begin{tabular}{|c|cccccc|}
\hline Code & Product name & 1997 & 2000 & 2005 & 2009 & 2012 \\
\hline 871 & Optical instruments and apparatus & 4.03 & 0.82 & 6.80 & 10.84 & 7.92 \\
793 & Ships, boats and floating structures & 6.96 & 7.57 & 9.09 & 9.88 & 7.64 \\
711 & $\begin{array}{c}\text { Steam boilers and auxiliary plant } \\
266\end{array}$ & 0.32 & 3.89 & 2.87 & 4.24 & 4.94 \\
655 & $\begin{array}{c}\text { Synthetic fabrics suitable for } \\
\text { spinning }\end{array}$ & 7.01 & 6.61 & 5.37 & 5.07 & 4.75 \\
233 & Knitted or crocheted fabrics & 5.48 & 5.84 & 4.83 & 4.83 & 4.41 \\
511 & Rubber, synthetic, reclaimed & 1.59 & 2.16 & 2.70 & 3.83 & 4.31 \\
513 & Hydrocarbons n.e.s., derivatives & 3.32 & 3.84 & 3.45 & 3.82 & 4.24 \\
776 & $\quad$ Carboxylic acids, etc. & 2.09 & 2.51 & 3.44 & 4.14 & 3.50 \\
724 & $\begin{array}{c}\text { Integrated circuits, and electronic } \\
\text { components }\end{array}$ & 3.68 & 2.89 & 2.67 & 2.26 & 3.04 \\
\hline $\begin{array}{c}\text { Textile \& leather machinery and } \\
\text { parts }\end{array}$ & 1.25 & 1.24 & 2.06 & 3.29 & 2.95 \\
\hline
\end{tabular}

Source: Authors' calculation based on database of UNSD 2014

Korea, on the other hand, enjoys a comparative advantage primarily in machineries and transport equipments. The main comparative advantage product groups of Korea include optical instruments and apparatus (871); ships, boats, and floating structures (793); stream boilers and auxiliary plant (711). More importantly, Korea has been able to increase its comparative advantage in high-technology manufacture product groups such as stream boilers and auxiliary plant (711) and textile \& leather machinery and parts (724).

As a result of the differences between the two countries' comparative advantages, the overlap of the RCA index between the two countries had not been significant. Less than 10 product groups evidenced a comparative advantage in both countries during the 1990s and 2000s (Kien, etc, 2010). Table 13 reveals that there have been a significant increase in the number of the RCA index overlapping between Korea and Vietnam during 2009-2012. However, these product groups accounted for a minimal export value to both Korea and Vietnam. From these results, we conclude that the structure of bilateral trade between Korea and Vietnam is complementary rather than competitive following their factor proportions. More specifically, Korea has demonstrated a comparative advantage in capitaland technology- intensive manufacturing product groups, whereas Vietnam has enjoyed a comparative advantage in labor- and resource intensive product groups. 
Table 13.

Overlap of RCA Index between Korea and Vietnam

\begin{tabular}{|c|c|c|c|c|}
\hline Year & Code & Product name & Korea & Vietnam \\
\hline \multirow{7}{*}{2009} & 651 & Textile yarn & 1.03 & 4.60 \\
\hline & 773 & Equipment for distributing electricity & 1.18 & 2.71 \\
\hline & 612 & $\begin{array}{c}\text { Manufactures of leather/of composition leather } \\
\text { n.e.s. }\end{array}$ & 1.13 & 2.36 \\
\hline & 611 & Leather & 1.40 & 2.20 \\
\hline & 653 & Fabrics, woven, of man-made fabrics & 2.13 & 2.03 \\
\hline & 266 & Synthetic fibers suitable for spinning & 5.07 & 1.71 \\
\hline & 657 & Special textile fabrics and related products & 1.36 & 1.07 \\
\hline \multirow{12}{*}{2012} & 711 & Steam boilers and auxiliary plant & 4.94 & 1.30 \\
\hline & 266 & Synthetic fabrics suitable for spinning & 4.75 & 1.88 \\
\hline & 655 & Knitted or crocheted fabrics & 4.41 & 1.17 \\
\hline & 724 & Textile \& leather machinery and parts & 2.95 & 1.15 \\
\hline & 653 & Fabrics, woven, of man-made fabrics & 2.06 & 2.19 \\
\hline & 764 & Telecommunications equipment and parts & 2.06 & 4.76 \\
\hline & 693 & Wire products and fencing grills & 1.51 & 1.48 \\
\hline & 611 & Leather & 1.34 & 1.75 \\
\hline & 773 & Equipment for distributing electricity & 1.09 & 3.07 \\
\hline & 951 & Armoured fighting vehicles, arms of & 1.06 & 1.37 \\
\hline & 651 & Textile yarn & 1.03 & 4.93 \\
\hline & 847 & Clothing accessories of textile fabrics & 1.01 & 1.54 \\
\hline
\end{tabular}

Source: Authors' calculation based on database of UNSD 2014

To evaluate the potential to expand bilateral trade between Korea and Vietnam, we constructed the trade complementarity index (TCI) for Korea's major trading partners using product groups at the three-digit SITC level for 1995-2011 period. The index indicates the degree to which the structures of a country's imports and exports match. TCI is measured as follows,

$$
T C I_{i j}=1-\sum_{n}\left(\frac{\left|m_{n i}-a_{n j}\right|}{2}\right)
$$


Where $m_{n i}$ is the share of goods, $n$, in the total imports of country $i$, whereas $a_{n j}$ is the share of goods, $n$, in the total exports of country $j$. The index equals zero when none of the goods exported by one country is imported by the other, whereas the index equals one when the export and import shares match exactly. The more similar two countries' export and import structures are, the closer the value of the TCI is to unity. Therefore, changes in the value of TCI over time can help us understand whether two countries' trade profiles are becoming more, or less, compatible. In this study, the TCI was calculated for Korea's 15 major trading partners.

Table 14.

Korea's Trade Complementarity Index with Major Trading Partners, 1995-2011

\begin{tabular}{|c|c|c|c|c|c|c|}
\hline Country & $\mathbf{1 9 9 5}$ & $\mathbf{2 0 0 0}$ & $\mathbf{2 0 0 5}$ & $\mathbf{2 0 0 9}$ & $\mathbf{2 0 1 0}$ & $\mathbf{2 0 1 1}$ \\
\hline Singapore & 64.7 & 65.2 & 57.8 & 59.3 & 58.6 & 65.8 \\
\hline Mexico & 51.0 & 58.4 & 61.9 & 61.3 & 62.6 & 62.6 \\
\hline Brazil & 50.9 & 54.8 & 51.9 & 58.4 & 61.1 & 62.5 \\
\hline China & 52.6 & 63.2 & 64.6 & 60.9 & 61.7 & 62.4 \\
\hline Sweden & 56.5 & 59.2 & 54.9 & 53.8 & 52.9 & 60.1 \\
\hline Malaysia & 60.2 & 61.2 & 61.3 & 60.9 & 62.1 & 60.0 \\
\hline Vietnam & 49.1 & 51.9 & 51.9 & 55.9 & 57.1 & 58.4 \\
\hline Argentina & 52.0 & 55.0 & 58.3 & 55.4 & 56.0 & 57.4 \\
\hline Philippines & 62.3 & 59.3 & 56.4 & 60.0 & 61.7 & 56.3 \\
\hline Indonesia & 47.4 & 56.3 & 60.1 & 60.7 & 59.2 & 55.5 \\
\hline Thailand & 55.9 & 63.3 & 56.3 & 59.6 & 58.2 & 55.5 \\
\hline Germany & 57.5 & 57.9 & 55.7 & 53.8 & 53.8 & 55.2 \\
\hline Hong Kong, China & 64.9 & 68.7 & 61.1 & 55.4 & 54.2 & 54.1 \\
\hline Canada & 53.0 & 54.2 & 51.6 & 52.0 & 51.5 & 53.5 \\
\hline Australia & 56.4 & 60.6 & 55.5 & 52.4 & 51.3 & 52.1 \\
\hline
\end{tabular}

Source: TRAINS, 2014

The results of TCI is consistent with our findings from the RCA index, which demonstrate that bilateral trade between Korea and Vietnam is getting more complementary due to the vertical integration through production sharing. Among the countries estimated, Korea has relatively high TCI values with Singapore, Mexico, Brazil, China, Malaysia, and Vietnam. This means that Korea's export structure is compatible with Vietnam's import structure. Korea's export structure fits well with Vietnam's import needs. Therefore, Korea 
has a high potential to increase its exports to Vietnam. On the other hand, low TCI values are found between Korea and countries like Germany, Hong Kong, Canada, and Australia.

\section{Conclusion}

The bilateral trade patterns and traits between Korea and Vietnam are the major focuses of this paper. The study derives the following conclusions. First, the structure of trade pattern between Korea and Vietnam conforms to the factor proportion theory. While Korea's exports to Vietnam have been mainly manufactured products, Vietnam's exports of primary and consumption goods to Korea accounted for a large proportion of its total exports. Second, the degree of intra-industry trade between Korea and Vietnam has been very low and unstable. This implies that the two countries differ in the degree of economic development. Third, the analysis of comparative advantages of products in Korea and Vietnam reveals that the trade structure between Korea and Vietnam is complementary not competitive in nature. While Vietnam enjoys a comparative advantage in either primary products or low-technology manufactured goods, Korea enjoys a comparative advantage in manufactured products and machinery and transport equipments. The high degree of trade complementarity between Korea and Vietnam implies that freer trade between the two is likely to bring about greater benefits for both Korea and Vietnam. Therefore, the proposed free trade agreement between Korea and Vietnam would explore each country's advantage in order to tighten and broaden the bilateral trade relations between Korea and Vietnam. Overall, we can conclude that the vertical integration through production sharing between the two has deepened and broadened over the past two decades while Vietnam has not succeeded in climbing the industrial staircase from resource and labor driven stage towards capital and technology intensive one. Areas of further research for the trade relations between Korea and Vietnam include the determinants of indigenous technology development, effective policy tools for technology transfer, and the nature and mechanism of technology catch-up in emerging economies. 


\section{References}

Gaulier, Guilaume, F. Lemoine, and U. Kesenci. 2005. China's Integration in East Asia: Production Sharing, FDI and High-tech Trade. CEPII Working Paper 2005/09. Paris:Research Center in International Economics.

Foreign Investment Agency (FIA), (2014), Inward Foreign Direct Investment, website: http://fia.mpi.gov.vn/news.aspx?ctl=news\&p=2.39\&mID=8, (accessed April 10, 2014).

Hoekman, Bernard M., Aaditya Mattoo, and Philip English. 2002. Development, Trade and the WTO: A Handbook. Washington, D.C.: World Bank.

Kien, Tran Nhuan, Hong Ryul Lee and Yoon Heo. 2010. Dynamic Patterns of Korea-Vietnam Trade Relations, International Area Review, 10 (2): 257-279.

KITA. 2014. Trade Statistics by Country. Seoul: Korea International Trade Association. http://global.kita.net/.

Lall, S. 2000. The Technological Structure and Performance of Developing Country Manufactured Exports 1985-98. Oxford Development Studies 28: 337-369.

Sachs, J.D. and A.M. Warner. 1997. Fundamental Sources of Long run Growth. American Economic Review 87 (2): 184-88.

United Nations Conference on Trade and Development. 2014. Trade Analysis and Information System (TRAINS). http://r0.unctad.org/trains_new/index.shtm (accessed April 10, 2014).

United Nations Statistics Division. 2014. United Nations Commodity Trade Statistics Database. http://comtrade.un.org/db/default.aspx (accessed April 10, 2014). 